\title{
Modular Design of Immunological Synapses and Kinapses
}

\author{
Michael L. Dustin \\ Program in Molecular Pathogenesis, Skirball Institute for Biomolecular Medicine, The Helen L and \\ Martin S Kimmel Center for Biology and Medicine, New York University School of Medicine, \\ New York 10016. \\ Correspondence: michael.dustin@med.nyu.edu
}

\begin{abstract}
The concept of an immunological synapse goes back to the early 1980s with the discovery of the relationship between T-cell antigen receptor mediated $\mathrm{Ca}^{2+}$ signaling, adhesion, and directed secretion. However, this concept did not gain traction until images were published starting in 1998 that revealed a specific molecular pattern in the interface between T cells and model antigen-presenting cells or supported planar bilayers. The dominant pattern, a ring of adhesion molecules surrounding a central cluster of antigen receptors, was observed in both model systems. Analysis of the origins of this pattern over the past 10 years has presented a solution for a difficult problem in lymphocyte biology-how a highly motile cell can suddenly stop when it encounters a signal delivered by just a few antigenic ligands on the surface of another cell without disabling the sensory machinery of the motile cell. The T lymphocyte actively assembles the immunological synapse pattern following a modular design with roots in actin-myosin-based motility.
\end{abstract}

$T^{1}$ he immune system provides an outstanding model for study of both dynamic and stable cell-cell adhesion (Dustin and Springer 1989; Lawrence and Springer 1991; Miller et al. 2002; Mempel et al. 2004). Early studies on molecules important for the function of cytotoxic lymphocytes, cells that kill virally infected cells and contribute to destruction of transplanted organs and tumors, identified two families of adhesion molecules (Davignon et al. 1981) (Fig. 1). Monoclonal antibodies that blocked the activity of cytotoxic lymphocytes identified an integrin, still widely referred to as LFA-1, and two immunoglobulin superfamily members, LFA-2 and LFA-3, now known more commonly as CD2 and CD58, respectively (SanchezMadrid et al. 1982). CD2 and CD58 were defined as a receptor ligand pair making it the first clearly defined heterophilic cell-cell adhesion system (Dustin et al. 1987a; Selvaraj et al. 1987). The identification of a ligand for LFA-1, ICAM-1, revealed that it too was a transmembrane member of the immunoglobulin superfamily providing a mechanism for involvement of integrins in cell-cell junction formation (Marlin and Springer 1987). These studies were contemporaneous with evidence for adhesion via direct ligand binding as a mechanism of matrix binding integrins, and homophilic interactions of NCAM and cadherins

Editors: W. James Nelson and Elaine Fuchs

Additional Perspectives on Cell Junctions available at www.cshperspectives.org

Copyright (C) 2009 Cold Spring Harbor Laboratory Press; all rights reserved; doi: 10.1101/cshperspect.a002873

Cite this article as Cold Spring Harb Perspect Biol 2009;1:a002873 
M.L. Dustin

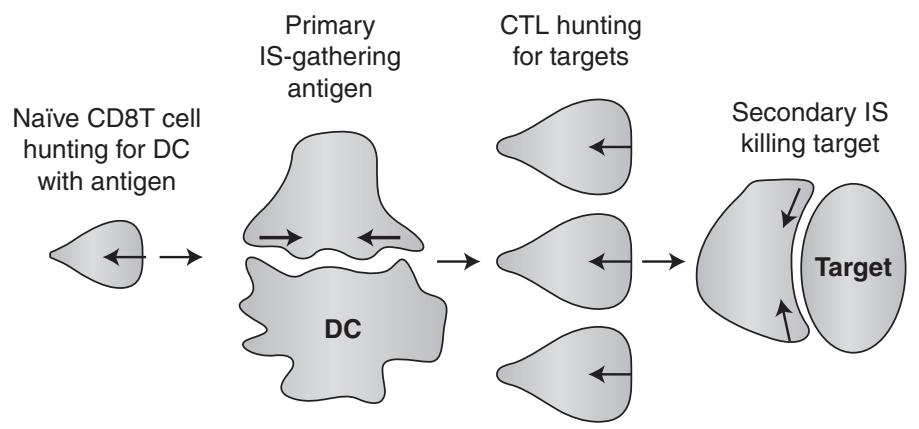

Figure 1. Cytotoxic T lymphocyte (CTL) life cycle. Naïve cells hunt for evidence of infection on the surface of self dendritic cells in lymphoid tissue. One antigen, if found on the primary immunological synapse, leads to activation, proliferation, and development of a CTL. This CTL exits the lymph node and uses the blood to reach a tissue. In the tissue, the CTL migrates to find its target and then uses a secondary synapse to kill the target.

(Rutishauser et al. 1982; Peyrieras et al. 1983; Gardner and Hynes 1985; Horwitz et al. 1985; Pytela et al. 1985; Wright and Meyer 1985; Cunningham et al. 1987; Nagafuchi et al. 1987). In some respects, the complexity of the role of oligosaccharides in NCAM-mediated adhesion and studying homophilic systems has resulted in clearer results coming from the heterophilic immune cell adhesion systems in the early to mid 1980s. It was speculated that the $\mathrm{CD} 2-\mathrm{CD} 58$ interaction might have evolved from an ancestral homophilic system like NCAM and subsequently it has been determined that CD58 is located in a rapidly evolving gene cluster including several important homophilic adhesion molecules on chromosome 1 (Wong et al. 1990). The number of receptor ligand interactions that are involved in immune cell interactions has grown significantly since these early studies, but the LFA-1/ ICAM-1 and CD2 family interactions still appear to be major contributors in cell adhesion in many functional settings. In this article, I review the role of LFA-1/ICAM-1, CD2/ CD58, and CD2 family homophilic adhesion molecules, like SLAM, in immune cell interactions. I describe the supported planar bilayer model in some detail because this has played an important role in the characterization of immune-cell adhesion systems, but also discuss recent studies using in vivo imaging that have also provided insight into the unique demands of in situ immune-cell interactions leading to specific molecular requirements.

\section{DISCOVERY OF ADHESION RECEPTORS IN THE IMMUNE SYSTEM}

An antigen is any chemical structure that can be recognized by the immune system (Lindenmann 1984). The adaptive immune system uses two types of cells to produce distinct types of antigen receptors. B cells recognize a wide variety of chemical structures from small molecules to conformation-sensitive determinants of biological macromolecules. B cells secrete copious amounts of these receptors, as antibodies, making them highly available biochemically such that their activity was discovered around 1900 and the molecule had been purified and sequenced by the 1960s. T cells were known to be important for protection against viruses and intracellular bacterial infections, and also provided help for B-cell responses, but the T-cell antigen receptor, which is not produced in an abundant secreted form, was more elusive. The focus of T-cell biology in the early 1980s was to discover this antigen receptor, which binds a ligand composed of antigen fragments bound to self major histocompatibility complex (MHC) molecules (Trombetta and Mellman 2005). Monoclonal antibodies were generated after immunization of mice with $\mathrm{T}$ cells and thousands were screened for ability to inhibit 
function one at a time. The Allison and Kappler and Marrack groups used monoclonal T cells as immunogens and testers to produce blocking antibodies to the $\mathrm{T}$-cell receptor (McIntyre and Allison 1983; White et al. 1983). When polyclonal T cells were used, the major functionblocking antibodies were not against the antigen receptor, because a polyclonal population contains many different structurally distinct antigen receptors, but were against adhesion molecules that are invariant and required for killing. Sanchez-Madrid and Springer produced the most complete panel, which included antibodies to LFA-1, CD2, and CD58, mentioned above (Sanchez-Madrid et al. 1982).

By 1984, it was shown that these antibodies inhibited function by blocking adhesion (conjugate formation between CTLs and target cells), and evidence was generated by 1986 that CD2 and CD58 were a receptor ligand pair, as mentioned above (Krensky et al. 1984; Shaw et al. 1986). Like NCAM, CD58 exists in transmemebrane and glycolipid-anchored splice variants (Dustin et al. 1987b). In the rodent models, there is no CD58, but CD2 binds to the related glycolipid-anchored CD48 (Kato et al. 1992). Antibodies to LFA-1 ligands were not discovered in these screens because there are multiple ligands that all need to be blocked at the same time to prevent killing, but the mAb were only tested one at a time. The first LFA-1 ligand to be identified was the inflammationregulated protein ICAM-1, which was discovered through generation of monoclonal antibodies to cells from children lacking LFA-1 and related $\beta 2$ integrins (Dustin et al. 1986; Rothlein et al. 1986). ICAM-2 was then identified from an endothelial-cell library by expression cloning (Dustin and Springer 1988; Staunton et al. 1989). ICAM-3 is expressed on leukocytes, ICAM-4 is expressed on red blood cells, and ICAM-5 is expressed in the nervous system. CD2-CD58 and LFA-1-ICAM are the major cell-cell adhesion systems for human T cells.

\section{REGULATION OF LYMPHOCYTE ADHESION}

There are two major paradigms for regulation of lymphocyte adhesion that are directly related to function: extravasation and immunological synapse formation. In both cases, the adhesion molecules are subjected to significant although very different forces. To transit from the blood to tissues, lymphocytes must interact with the vessel wall under flow, arrest motion with the blood flow, and polarize and crawl between or through endothelial cells (Springer 1995). The cells then read tissue queues to drive cell migration. To communicate with antigenpresenting cells, the highly polarized migrating $\mathrm{T}$ cells must arrest migration and form a tight cell-cell junction for minutes to hours (Mempel et al. 2004). The specialized cell-cell junction that mediates this arrest and subsequent communication is referred to as an immunological synapse (Grakoui et al. 1999). The forces experienced by the extravasating cells are external forces of blood flow generating $\sim 200 \mathrm{pN}$ forces on molecular interactions that are tethering cells, whereas the forces experienced by cells migrating in tissues or forming an immunological synapse are on the order of $2 \mathrm{pN}$, the force transmitted by the cytoskeletal adapter talin (Jiang et al. 2003; Alon and Dustin 2007). Surprisingly, a single versatile adhesion molecule, LFA-1, dominates both processes.

LFA-1 functions as an adhesion molecule and is regulated by at least three mechanisms-changes in conformation driven by inside-out signaling, changes in organization secondary to increased lateral mobility, and force-dependent adhesion strengthening that is related to fluid shear. The LFA-1 ligand binding domain can exist in three conformations: a low affinity conformation with a $\mathrm{Kd}$ of approximately $1 \mathrm{mM}$, an intermediate affinity form with a Kd of approximately $10 \mu \mathrm{M}$, and a high affinity form with a $\mathrm{Kd}$ of approximately $100 \mathrm{nM}$ (Shimaoka et al. 2003). The intermediate affinity form is the likely substrate for regulation of LFA-1 through changes in lateral mobility and clustering, and the high affinity form may be achieved when LFA-1 is subjected to specific forces following intermediate affinity binding. This ability to shift to a higher affinity in response to force may give LFA-1 the appearance of a catch bond and 
M.L. Dustin

allow it to operate under conditions that would undermine a fixed affinity adhesion system. Application of relatively low forces applied parallel to the membrane plane or greater forces applied perpendicular to the membrane may induce this high-affinity form (Zhu et al. 2008). High-affinity LFA-1 interacts with ICAM-1 with a half-life of $30 \mathrm{~s}$ in solution, but likely has a much shorter half-life with application of forces from the cytoskeleton or from fluid shear. Thus, even when the highaffinity form is generated in physiological settings, the interactions may appear much more dynamic because the high-affinity form may only be generated under forces that will dramatically shorten the interaction compared with solution measurements. Keeping the halflife in the interaction in the subsecond range under all conditions, with strengthening of the interaction when under shear forces, is ideal for the situation in which the lymphocyte not only needs to arrest on the vessel wall, but also to migrate to endothelial cell junctions for extra-vasation.

LFA-1 displays regulated adhesive interactions in both extravasation and immunological synapse formation. Regulation of LFA-1-mediated adhesion was first documented using phorbol-ester stimulated aggregation of lymphoblasts, a simple in vitro model (Rothlein and Springer 1986). In retrospect, the original descriptions of cell dynamics in phorbol-ester stimulated lymphocyte aggregates are remarkably similar to recent description of B lymphoblasts in germinal centers of lymph nodes (Allen et al. 2007; Schwickert et al. 2007). The aggregation assay was used to identify ICAM-1 as a ligand for LFA-1, and it was also determined that phorbol esters stimulated aggregation without altering expression levels of LFA-1 and ICAM-1 (Dustin et al. 1986; Rothlein et al. 1986). Live cell adhesion to surfaces coated with purified LFA-1 or ICAM-1 revealed that $\mathrm{T}$ cell receptor (TCR) signaling stimulated changes in LFA-1 activity through signaling processes-described as inside-out signaling (Dustin and Springer 1989).

The concept of inside-out signaling was extended to the extravasation process, but using chemokines as triggers for inside-out signaling to LFA-1 and other integrins to induce arrest of leukocytes undergoing selectinmediated rolling adhesion on the vessel wall (Lawrence and Springer 1991). During extravasation, it has been argued by Alon and colleagues that LFA-1 is subject to very rapid activation that may reflect a preformed complex between LFA-1 and chemokine receptors (Shamri et al. 2005).

The detailed mechanism by which insideout signaling operates is not known. TCR crosslinking initiates a tyrosine kinase cascade that activates the Rac GTP exchange factor (GEF) Vav and the Rap 1 GEF C3G (Krawczyk et al. 2002; Nolz et al. 2008). Rap-1 activation of RIAM is thought be an important step in the recruitment of Vinclulin and Talin to nascent adhesion (Nolz et al. 2007). The activation of LFA-1 by inside-out signaling results in significant recruitment of the cytoskeletal adapter talin to the interface, consistent with Talin as an integrator (Tadokoro et al. 2003). Talin is recruited to areas of LFA-1/ICAM-1 interaction whether this adhesion is triggered by acute TCR signaling or by cytokine and cell-cycle mediated activation (Somersalo et al. 2004; Smith et al. 2005). Talin knockdown results in decreased LFA-1 mediated adhesion both in migrating lymphoblasts and in cells forming immunological synapses. Whether this also impacts adhesion under shear flow has not been determined.

Recently, it has been shown that the in vivo interaction of $\mathrm{T}$ cells and $\mathrm{B}$ cells, but not $\mathrm{T}$ cells and dendritic cells, depends on the small SH2 domain-only adapter protein SAP (Qi et al. 2008). SAP is mutated in X-linked immunodeficiency, which is characterized by loss of T-cell dependent antibody production. SAP interacts with a subfamily of homophilic adhesion molecules, including SLAM, NTB-A, Ly9, and CD84. These interactions appear to be important for stable adhesion between T and B cells, but it is not clear if this is because of adhesive energy provided by the homophilic interactions or if they mediate a signal via SAP that enhances stability of LFA-1 dependent adhesion. SAP interacts with the phosphorylated cytoplasmic 
Modular Design of Immunological Synapses and Kinapses

domain of SLAM, NTB-A, Ly9, and CD84, and with the Src family kinase Fyn via an unconventional interaction with its $\mathrm{SH} 3$ domain (Latour et al. 2003). The immunological synapse formed by $\mathrm{T}$ and $\mathrm{B}$ cells in vivo is much more dynamic than the structure characterized in vitro in that the $\mathrm{B}$ cell remains highly motile and appears to drag the $\mathrm{T}$ cell (Okada et al. 2005). Thus, B cells do not appear to experience a stop signal in this interaction. It is not clear whether the essential role of SAP and the associated adhesion systems is based on direct stabilization of adhesion by these interactions or if signaling through this pathway helps to stabilize other adhesion mechanisms.

\section{DEFINING SYNAPSE}

Synapse is a term derived from Greek that means "to fasten onto": As chromosomes fasten to each other during meiosis, synaptic boutons fasten onto dendritic spines or $\mathrm{T}$ lymphocytes fasten onto antigen-presenting cells. The concrete definition proposed in essentially all of these contexts is a stable junction that allows for a functional outcome-recombination, relaying electrical impulses, or mediating immune cell communication or function. "Stable" is a relative term with times lasting from minutes in meiosis, to hours or days for immune cells, and months to years for neural synapses. Thus, the immune cell synapses are considered stable relative to the highly dynamic behavior of lymphocytes in secondary lymphoid tissues where they migrate at up to $30 \mu \mathrm{m} / \mathrm{min}$ (Miller et al. 2002). "Immunological synapse" was not used in a peer-reviewed publication until 1998, although it appeared in two speculative reviews published in 1984 and 1994 (Norcross 1984; Paul and Seder 1994). The observations that gave this concept traction in 1998 were images from Kupfer of the interface between $\mathrm{T}$ cells and antigen-presenting cells that were fixed at different time points, bound with fluorescently tagged antibodies, and then visualized by deconvolution microscopy (Monks et al. 1998). These images revealed a discrete central cluster of T-cell receptors surrounded by a

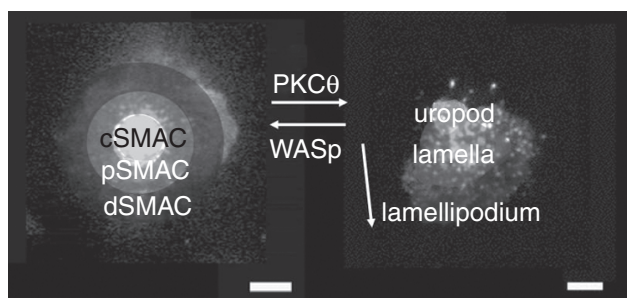

Figure 2. SMAC and kinapse zones. Immunological synapses may have a central cSMAC, an annular pSMAC, and an outer dSMAC. The cSMAC can be rich in TCR-peptide-MHC interaction. The pSMAC is enriched in LFA-1-ICAM-1 interactions. These structures are normally in the interface between two cells, but can be modeled using a live $\mathrm{T}$ cell interacting with a supported planar bilayer. A kinapse is a mobile junction with the arrow reflecting the direction of motion. The leading edge is the lamellipodium, the wide region is the lamella or focal zone, and the trailing edge is the uropod. These zones are shaded over images showing the pattern of T-cell receptors.

ring of adhesion molecules on a supramolecular scale. Kupfer defined three supramolecular activation clusters (SMACs): central (cSMAC), perpheral (pSMAC), and distal (dSMAC) (Fig. 2) (Monks et al. 1998; Freiberg et al. 2002). The cSMAC contained TCR, peptide-MHC, and protein kinase C- $\theta$. The pSMAC contained LFA-1, talin, and ICAM-1. The dSMAC appeared enriched in CD45 (Johnson et al. 2000; Freiberg et al. 2002), but this may be an optical artifact arising from two closely apposed plasma membranes in a sheetlike projection of lamellipodium, as we discuss in the following section. We observed similar segregation and organization of adhesion molecules in the interface between $\mathrm{T}$ cells and supported planar bilayers (Fig. 3) containing purified ligands from the antigen-presenting cells and further linked this to control of cell polarity (Dustin et al. 1998). We initially proposed a definition of immunological synapse as having a combination of a "specialized (adhesive) junction, cell polarization, and positional stability" (Dustin et al. 1998). In 2002, David Coleman and I considered four criteria: (1) cells remain individual; (2) the apposed membranes are held together by adhesion molecules; (3) the junction is stable 
M.L. Dustin

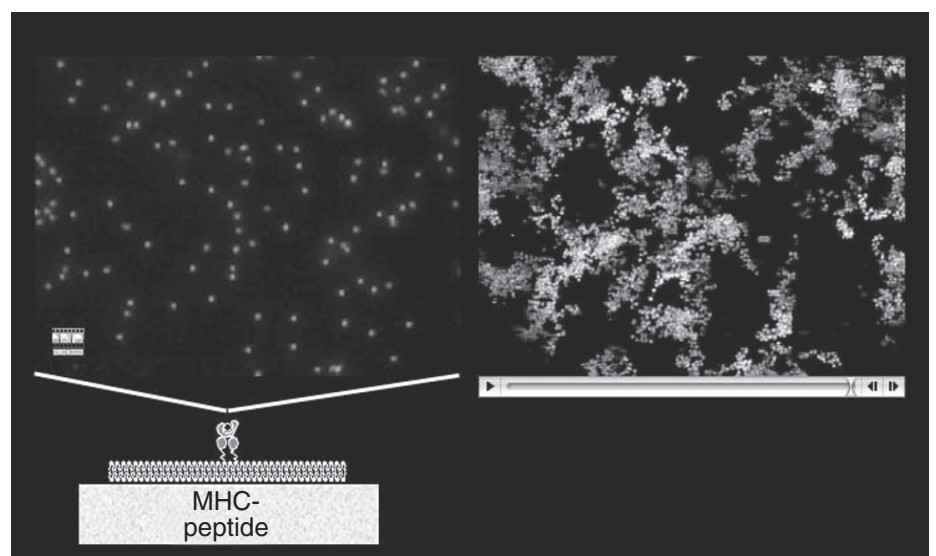

Figure 3. Supported planar bilayers. Supported planar bilayers have been used to model the immunological synapse. A remarkable property of planar bilayers is that the lipids, and anything linked to them, are laterally mobile. The left image shows single CD58 molecules in a bilayer labeled with $100 \mathrm{~nm}$ fluorescent latex spheres. The left image is based on running background subtraction with peak detection from a 30-s movie and illustrates the areas covered by single diffusing particles in the bilayer. Each particle covers roughly the area of an immunological synapse in $30 \mathrm{~s}$.

either through adhesion clamp or cytoskeletal polarity; and (4) directed secretion in response to signals from microdomains (Dustin and Colman 2002). These criteria applied equally well to neural and immunological synapses. Immunological synapses are considered stable based on their remaining symmetric and within the same cell sized area for 20-30 minutes (Grakoui et al. 1999; Sims et al. 2007). The immunological synapse defined by our studies is very similar to the SMAC defined in Kupfer's 3D analysis of T-cell-APC conjugates such that the SMACs are considered components of the immunological synapse (Fig. 4).

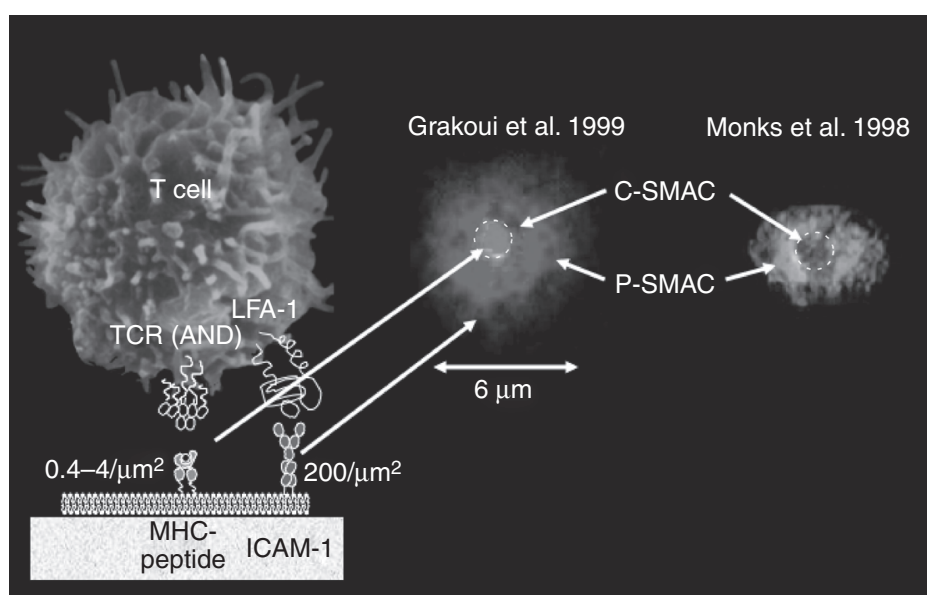

Figure 4. Reconstitution of the immunological synapse with a planar bilayer. The image on the far right is a slice from the interface between B cells and T cells showing the cSMAC and pSMAC. The schematic and image on the left are of the planar bilayer containing only ICAM-1 and peptide-MHC. The same pattern is formed, although the contact synapse area is larger on the planar surface. The dSMAC was not labeled in these images. 


\section{DEFINING KINAPSE}

Parallel studies on T-cell interactions with dendritic cells in vitro observed highly dynamic interactions between $\mathrm{T}$ cells and dendritic cells or macrophages, particularly when the cells were embedded in collagen gels (Underhill et al. 1999; Gunzer et al. 2000). These observations raised questions about whether the more stable cell-cell interactions were physiological. In the past 6 years the use of intravital microscopy to peer directly into living lymphoid tissues of mice revealed that both modes of interaction are observed in vivo. As mentioned previously, $\mathrm{T}$ cells are highly motile in secondary lymphoid tissues with average speeds between 10 and $15 \mu \mathrm{m} / \mathrm{min}$ and peak speeds of over $30 \mu \mathrm{m} / \mathrm{min}$. The mechanism of propulsion is not fully understood. The speed of motility is only weakly dependent on integrins like LFA-1 and is more dependent on $\mathrm{G}_{\mathrm{i}}$-protein coupled receptors that are sensitive to pertussis toxin. In vitro reconstitutions show that chemokines like CCL21, which bind to the receptor CCR7, can reconstitute strong T-cell polarization and rapid motility (Woolf et al. 2007). Thus, both polarity and sufficient traction can be generated by $G$ protein coupled receptors (GPCRs). We have observed that this mode of adhesion involves very small contact areas with essentially no detectable area of contact observed by interference reflection microscopy. This suggests that the $\mathrm{T}$ cells are only contacting the surface through small projections that make contact below the diffraction limit ( 200-300 nm). Including ICAM-1 on the substrate along with CCL21 allows the formation of measurable contact areas on the order of $50 \mu \mathrm{m}^{2}$ in size (Huang and Dustin, unpublished observations). It is known that the LFA-1-ICAM-1 interaction increases T-cell sensitivity to antigen by 10 - to 100 -fold and this may correspond to the increase in contact area formed by $\mathrm{T}$ cells and APC, which is on the order of 10- to 100-fold (Schmits et al. 1996; Bachmann et al. 1997). These mobile scanning contact areas are the foundation of the kinapse-a moving junction that allows $\mathrm{T}$ cells to scan self and foreign MHC-peptide complexes and costimulatory ligands. Although the synapse is symmetric in the plane of the contact area, the kinapse is asymmetric and this is critical to control stopping and going. The asymmetric kinapse has a leading lamellipodium, an intermediate lamella, and a trailing uropod (Fig. 2). Therefore the kinapse is an adhesion-dependent junction, like the synapse, but it is mobile rather than stable, and it is not an efficient platform for directed secretion.

\section{ELEMENTS OF THE IMMUNE CELL CYTOSKELETON}

Like other motile cell types, immune cells possess and use the three major filament systems-actin thin filaments, vimentin intermediate filaments, and tubulin-based microtubules. The role of microtubules and the actin cytoskeleton in organizing conjugate formation has been appreciated since the early 1980s based on studies with natural killer (NK) cells and T lymphocytes. The interest in the intermediate filament system has focused on the manner in which circulating lymphocytes survive blood flow by building a vimentin cage that needs to be rapidly disassembled in response to chemokine signals to permit adhesion to the vessel wall and extravasation (Brown et al. 2001).

The microtubule system in lymphocytes is characterized by an astral organization with a central hub or microtubule organizing center (MTOC) collecting all of the minus ends and the plus ends extending through the thin cytoplasm around the nucleus toward the opposite pole of the cell. Early studies from Berke and Singer laboratories showed that the microtubule organizing center of CTLs and NK cells, respectively, docks to the synapse during cell mediated killing (Geiger et al. 1982; Kupfer et al. 1983). Kupfer and Singer extended these findings during the 1980s and 1990s to helper $\mathrm{T}$ cells, and developed the hypothesis that the MTOC brings with it the Golgi apparatus and a means for directed secretion of cytokines by helper T lymphocytes (Kupfer et al. 1986). More recently, it has been shown that although the Golgi is focused at the synapse with the 
M.L. Dustin

MTOC, some proteins that transit the Golgi, like the cytokine IL-4, are released away from the synapse, whereas others like IFN- $\gamma$ are released toward the synapse (Huse et al. 2006). The polarity of release of cytolytic granules, on the other hand, is independent of the Golgi positioning and requires the direct docking of the MTOC through which the microtubules recruit the granules to the membrane to allow efficient release of granule contents into the synaptic cleft (Stinchcombe et al. 2006).

The actin system of lymphocytes is dominated by microvilli in circulating lymphocytes that are remodeled into an amoeboid organization during chemokine-mediated transit from blood to tissues (Nijhara et al. 2004). The amoeboid pattern is characterized by dynamic actin at the leading edge and a myosin II enriched uropod at the trailing edge. The MTOC remains behind the nucleus in the uropod. In the early 1980s, Carpen and Saksela showed a distinct polarization of F-actin to the synapse between NK cells and target cells (Carpen et al. 1983). Subsequently, Kupfer and Singer showed that talin, a protein identified as linking the extracellular matrix receptor complexes to F-actin, was also concentrated in the synapse in an antigen-dependent manner (Kupfer and Singer 1989). The discovery that LFA-1 and the extracellular matrix families were both members of the same protein family, the integrins, solidified the appreciation of talin as a link between ICAM-1 on the antigen-presenting cell, LFA-1 and the $\mathrm{T}$ cells, and synaptic F-actin in the T-cell cytoskeleton. Because ICAM-1 is also cytoskeletally associated with ezrin/radixin/ moesin (ERM) family proteins in the antigen presenting cells, this system "integrates" the antigen presenting cell and $\mathrm{T}$ cell surfaces and cytoskeleton into a single supramolecular system-later defined by Kupfer as the pSMAC.

T cells also use the ERM system of proteins, but the exact manner and functional significance of these interactions in $\mathrm{T}$ cells has been controversial. T cells express ezrin and moesin. ERM proteins are important in formation of microvilli and the dephosphorylation of ERM proteins mediated by chemokine signals in circulating lymphocytes allows spreading and extravasation (Brown et al. 2003; Nijhara et al. 2004). There is general agreement that moesin is excluded from the immunological synapse and moves either out of the synapse or to a distinct distal-pole complex where a number of signaling molecules are deposited during activation (Allenspach et al. 2001; Delon et al. 2001; Ilani et al. 2007; Shaffer et al. 2009). The general model is that moesin is constitutively active in linking F-actin to proteins like CD43. When $\mathrm{T}$ cells are activated, moesin is phosphorylated in a TCR and Vav-1 dependent manner and this causes its dissociation from membrane proteins. This dephosphorylation is partial and much moesin remains membrane associated outside the contact area. Ezrin dynamics are more complicated and it's agreed that it remains associated with the F-actin rich regions of the synapse, at least transiently (Allenspach et al. 2001; Ilani et al. 2007; Shaffer et al. 2009). Movement of CD43 to the uropod of migrating $\mathrm{T}$ cells, which is dependent on interaction with ERM proteins, assists disengagement of LFA-1 (Savage et al. 2002). Global dephosphorylation of ERM proteins in the cell also appears to "relax" the cortex of the cell and allow spreading using dynamic F-actin (Faure et al. 2004). It has also been proposed that ezrin, which has an immunotyrosine activation motif-like (ITAM-like) sequence and lingers in the actin rich areas of the synapse, may be important for activation of ZAP-70 in the immunological synapse (Ilani et al. 2007), although mouse $\mathrm{T}$ cells deficient in ezrin appeared to have normal ZAP-70 activation (Shaffer et al. 2009). In the later study, both ezrin and moesin contributed to $\mathrm{T}$ cell IL-2 production, although they displayed a different localization (Shaffer et al. 2009).

A highly dynamic F-actin network characterizes the lamellipodia of motile cells. Dynamic actin is composed of a mixture of branched F-actin nucleated by the Arp $2 / 3$ and linear actin bundles nucleated by formins. At least two pathways contribute to dynamic F-actin networks in $\mathrm{T}$ cells, the WAVE2 
Modular Design of Immunological Synapses and Kinapses

complex, which is controlled by Rac small G-proteins (Gomez et al. 2006; Nolz et al. 2006; Gomez et al. 2007), and WASp, which is controlled by Cdc42 (Snapper et al. 1998; Cannon et al. 2001; Dupre et al. 2002; Sasahara et al. 2002; Labno et al. 2003). T cells also express myosin IIA, which may contribute to the cortical tension of the F-actin network along with poorly characterized myosin I isoforms (Pierce et al. 2001; Jacobelli et al. 2004; Kim et al. 2006; Morin et al. 2008). Lamellipodia undergo periodic extensions mediated by actin polymerization and retraction mediated by myosin II dependent contraction (Giannone et al. 2004; Giannone et al. 2007). The propagation of these contractile oscillations in lamellipodia represents a universal dynamic pattern in many motile cell types, including lymphocytes (Dobereiner et al. 2006). This appears to be a basic module from which both kinapses and synapses can be initiated.

\section{MODULAR ASSEMBLY OF KINAPSES AND SYNAPSES}

The lamellipodium functions as a sensory structure in T lymphocytes. The leading lamellipodium is several-fold more sensitive to antigen than other parts of a polarized $\mathrm{T}$ cell (Negulescu et al. 1996; Wei et al. 1999). These studies focused on the motile $\mathrm{T}$ cells or kinapse configuration. Immunological synapse formation also appeared to involve the extension of lamellipodial structures over the surface of the antigen-presenting cell (Grakoui et al. 1999; Dustin and Cooper 2000; Bunnell et al. 2001; Tskvitaria-Fuller et al. 2003). In these studies, this phase of extension and contraction appeared to be a one-time event, taking place in the first minutes of interaction, which then set up a highly stable adhesive clamp in the cSMAC (Grakoui et al. 1999). Two lines of experimentation shattered this perception. First, Varma applied TIRFM imaging to track TCR in the immunological synapse formed on supported planar bilayers with laterally mobile ligands and observed that the stable synapse contained within it a continual evolution of small TCR clusters in the periphery that streamed toward the center to sustain signaling (Fig. 5) (Varma et al. 2006). These TCR microclusters recruited a number of signaling molecules that were not recruited to the clamplike cSMAC, in which signaling appeared to be terminated (Campi et al. 2005; Yokosuka et al. 2005). T-cell activation by immobilized anti-CD3 antibodies also incorporated dynamic elements, including singlemolecule movement of Src family kinase Lck between signaling foci (Douglass and Vale 2005) and signaling adapter SLP-76-rich

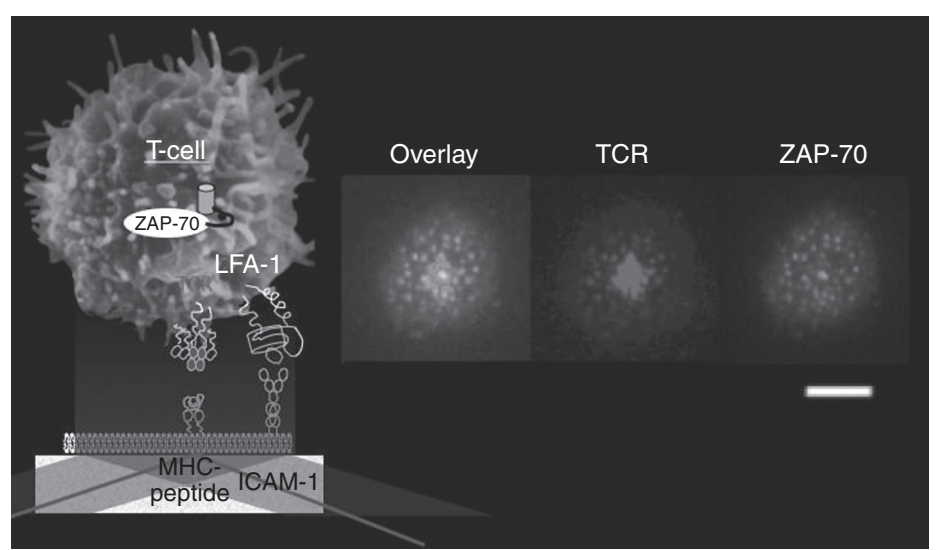

Figure 5. Snap shots of TCR microclusters in an immunological synapse. The images are frames from a movie showing the colocalization of TCR and the kinase ZAP-70 (tagged with GFP) as detected by Campi and Varma by TIRFM microscopy (illustrated schematically on the left). 
M.L. Dustin

vesicles that underwent microtubule-directed centripetal motion (Bunnell et al. 2002; Barda-Saad et al. 2005; Barr et al. 2006). TCR microcluster movement could be interrupted by inhibition of actin polymerization, but not by depolymerization of microtubules (Varma et al. 2006). Static analysis of proteins involved in dynamic actin polymerization revealed the periphery of the immunological synapse was rich in Arp2/3, cofilin, and F-actin consistent with sustained lamellipodia-like activity (Sims et al. 2007). Dynamic analysis of the outer edge of stable synapses also showed a pattern of circumferential waves of extension and contraction that were remarkably similar to lateral waves in fibroblasts and epithelial cells (Dobereiner et al. 2006; Sims et al. 2007). Speckle microscopy of GFP-actin in a model immunological synapse showed rapid centripetal flow that was moving 2.4-fold faster than the TCR microclusters (Kaizuka et al. 2007). Rapid binding and dissociation of TCR microclusters from the centripetally moving F-actin was also supported by the ability of microclusters to run through nanofabricated mazes (DeMond et al. 2008). Not only the TCR, but the LFA-1 ring is a highly dynamic system built from microclusters that undergo constant turnover (Kaizuka et al. 2007; Sims et al. 2007). The stability of the synapse seems not to be built by clamping adhesion per se, but by taking a highly dynamic motile system and balancing out its motile tendencies through symmetry. Thus, the highly sensitive lamellipodial module can be used in the motile kinapse and the stable synapse.

Amoeboid locomotion uses a leading lamellipodium, a force integrating lamella and a contractile uropod for substrate sensing, traction, and disengagement (Jay et al. 1995; Gupton et al. 2005; Giannone et al. 2007). The kinapse appears to be similarly constructed with relatively discrete zones defined by F-actin, talin, and myosin IIA enrichment (Sanchez-Madrid and del Pozo 1999; Smith et al. 2005; Morin et al. 2008). The synapse formed on laterally mobile substrates such as planar bilayers displays a well-organized radial lamellipodium or dSMAC, an annular lamella or PSMAC, and, in the relative position of the uropod, a relatively F-actin free cSMAC. Although each of these modules has similarities between the kinapse and synapse, the imposition of radial symmetry and the functional specialization for secretion require modifications to each module.

The radially symmetric pSMAC has two important functions: stopping motility and containing materials directly secreted into the cSMAC. Stopping motility is the first critical function. The symmetry of the pSMAC can be modulated by intrinsic and extrinsic factors. Intrinsic factors include anergy, antagonism, and PKC- $\theta$ activation. Self-tolerance is a critical function of the immune system. T cells can be made self tolerant through deletion of the clone bearing a certain TCR, in which case this TCR specificity is lost, or by making the clone of $\mathrm{T}$ cells nonresponsive under most conditions - a state called "anergy." Anergic T cells activate a gene expression profile that leads them to express an array of ubiquitin ligases that targets signaling machinery and destabilizes the synapse (Heissmeyer et al. 2004). Anergic T cells break symmetry of the pSMAC within 10 minutes of contact and do not reform them. The default process when TCR signaling is disrupted is for the cells to break symmetry and convert to a kinapse, as is also observed when antagonist peptide-MHC complexes kinetically poison TCR signaling (Sumen et al. 2004). Protein kinase C- $\theta$ is in the novel subgroup, meaning that it is activated by diacylglycerol, but is insensitive to $\mathrm{Ca}^{2+}$. It is the only PKC isoform that is specifically recruited to the immunological synapse (Monks et al. 1997; Monks et al. 1998). PKC- $\theta$ deficient mice have a profound defect in T-cell activation because of deficits in NFKB activation via Carma-1 (Sun et al. 2000; Egawa et al. 2003; Lee et al. 2005). Time lapse imaging of T-cell activation using naïve $\mathrm{T}$ cells from these mice and with wild-type $\mathrm{T}$ cells treated with PKC- $\theta$ inhibitors revealed hyperstable immunological synapses (Sims et al. 2007). Analysis of Wiskott-Aldrich syndrome protein (WASp) deficient $\mathrm{T}$ cells revealed gross instability, which was converted to 
hyperstability by the PKC- $\theta$ inhibitor. In naïve $\mathrm{T}$ cells responding to antigens for the first time, the activity or PKC- $\theta$ induces symmetry breaking and kinapse formation, whereas WASp induced symmetry formation and synapse formation. This system is poised in wild-type $\mathrm{T}$ cells to induce cycles of synapse and kinapse formation with a periodicity of approximately 20 minutes (Sims et al. 2007). Our model is that PKC- $\theta$ undermines the integrity of the pSMAC actin network to break the annular structure open to generate a kinapse, whereas WASp contributes to actin polymerization positioned to repair the annular network and restore symmetry and the synapse. Extrinsic signals that can contribute to symmetry breaking are delivered by dominant chemokines like CCR7 and CXCR3 (Bromley et al. 2000; Molon et al. 2005), although this process has not been studied in detail. The concept that the pSMAC plays an important role in containing components that are released into the synapse has been tested directly by stabilizing pSMACs formed by $\mathrm{CD} 4^{+}$cytolytic T cells with a PKC- $\theta$ inhibitor, which increased killing efficiency by threefold (Beal et al. 2008). Immune cells appear to have a unique ability among cellular systems to modulate lamellar symmetry to achieve fine control of migration and cell-cell communication.

The correspondence of the uropod and cSMAC is less clear because the cSMAC is neither rich in myosin II nor a site of de-adhesion. The cSMAC is a relatively F-actin free zone, but it is not clear what mechanisms enforce this. The paucity of F-actin is functionally important because this appears to promote TCR signal termination (TCR signaling is F-actin dependent) (Varma et al. 2006), exclusion of LFA-1 (its interaction with ICAM-1 is F-actin dependent) (Kaizuka et al. 2007), and the access of secretory vesicles to the plasma membrane for synaptically directed secretion (Stinchcombe et al. 2006). How TCR clusters are moved into this F-actin free zone is not clear, but cSMAC formation appears to involve a fusion of structures that are initially jostling about in the center of the synapse (Varma et al. 2006). An important function of the cSMAC may be to sort different components from incoming TCR microclusters into distinct compartments. To be fully activated, a $\mathrm{T}$ cell needs to integrate both TCR and costimulatory signals. One type of costimulatory signal is delivered when CD28 on the surface of T cells interacts with CD80 or CD86 on the surface of the antigen-presenting cells. The level of expression of CD80 and CD86 on dendritic cells reflects the level of innate activation of the dendritic cells and thus serves to alert the immune system to microbial invasion, foreign bodies, and tissue injury. The CD28-CD80 complex has the same extracellular dimensions as the TCR-peptide-MHC complex, such that these pairs can and do comingle in the same microclusters (Springer 1990). Although the variable affinity TCR-peptide-MHC interactions can become irreversible at the higher end of the affinity spectrum and need to be degraded, the fixed affinity CD28-CD80 interaction is tuned to be readily reversible and can be recycled. Recently, Yokosuka et al. have shown that stable TCR-peptide-MHC interactions are sorted from more dynamic CD28CD80 interaction to form two compartments within the cSMAC (Yokosuka et al. 2008). The mechanism of this sorting process is currently not established, but my laboratory is currently working to test the hypothesis that endosomal sorting complexes required for transport (ESCRT) are required for this sorting and for cSMAC formation. Therefore, the cSMAC is likely the most unique module of the synapse configuration that has no counterpart in a kinapse. The combination of sorting, signaling, and secretion in this site suggest that this region combines several functional modules that have in common a need for relatively F-actin free access to the plasma membrane.

\section{CONCLUSIONS}

I have presented a reductionist view of this complex model system based largely on consideration of only a few adhesion systems used during T-cell function, which to some extent appears to provide a framework on which other molecules can be added. There are still 


\section{M.L. Dustin}

many open issues in our understanding of the immunological synapse in the context of cell biology and immunology. Many of the findings I have described are based on surrogate antigen presenting cells and have simplified the system to better understand the $\mathrm{T}$ cell side of the synapse/kinapse equation, but it is clear that different types of antigen-presenting cells make profound contributions to the outcome and are far from passive (Boes et al. 2002; Al-Alwan et al. 2003; Brossard et al. 2005; Tseng et al. 2008). Improved methods for highresolution imaging of T cells-APC conjugates will help to advance this cause (Oddos et al. 2008). Improvements in intravital microscopy and fluorescent proteins may also enable better descriptions of in vivo immune synapses and kinapses. Despite these limitations, the concept of symmetry and kinapse/synapse interconversion appears to be useful in vivo in which both behaviors are readily observed in protective responses and immunopathology (Sims et al. 2007; Skokos et al. 2007; Kim et al. 2009). A major goal of this work is to predict immune-cell behavior toward development of immunotherapies. It is likely that this depth of understanding will advance discoveries in cell biology.

\section{REFERENCES}

Al-Alwan MM, Liwski RS, Haeryfar SM, Baldridge WH, Hoskin DW, Rowden G, West KA. 2003. Cutting edge: Dendritic cell actin cytoskeletal polarization during immunological synapse formation is highly antigendependent. J Immunol 171: 4479-4483.

Allen CD, Okada T, Tang HL, Cyster JG. 2007. Imaging of germinal center selection events during affinity maturation. Science 315: 528-531.

Allenspach EJ, Cullinan P, Tong J, Tang Q, Tesciuba AG, Cannon JL, Takahashi SM, Morgan R, Burkhardt JK, Sperling AI. 2001. ERM-dependent movement of CD43 defines a novel protein complex distal to the immunological synapse. Immunity 15: 739-750.

Alon R, Dustin ML. 2007. Force as a facilitator of integrin conformational changes during leukocyte arrest on blood vessels and antigen-presenting cells. Immunity 26: 17-27.

Bachmann MF, McKall-Faienza K, Schmits R, Bouchard D, Beach J, Speiser DE, Mak TW, Ohashi PS. 1997. Distinct roles for LFA-1 and CD28 during activation of naive $T$ cells: Adhesion versus costimulation. Immunity 7: 549-557.
Barda-Saad M, Braiman A, Titerence R, Bunnell SC, Barr VA, Samelson LE. 2005. Dynamic molecular interactions linking the $\mathrm{T}$ cell antigen receptor to the actin cytoskeleton. Nat Immunol 6: 80-89.

Barr VA, Balagopalan L, Barda-Saad M, Polishchuk R, Boukari H, Bunnell SC, Bernot KM, Toda Y, Nossal R, Samelson LE. 2006. T-cell antigen receptor-induced signaling complexes: Internalization via a cholesteroldependent endocytic pathway. Traffic 7: 1143-1162.

Beal AM, Anikeeva N, Varma R, Cameron TO, Norris PJ, Dustin ML, Sykulev Y. 2008. Protein Kinase C $\theta$ Regulates Stability of the Peripheral Adhesion Ring Junction and Contributes to the Sensitivity of Target Cell Lysis by CTL. J Immunol 181: 4815-4824.

Boes M, Cerny J, Massol R, Op Den Brouw M, Kirchhausen T, Chen J, Ploegh HL. 2002. T-cell engagement of dendritic cells rapidly rearranges MHC class II transport. Nature 418: 983-988.

Bromley SK, Peterson DA, Gunn MD, Dustin ML. 2000. Cutting edge: Hierarchy of chemokine receptor and TCR signals regulating T cell migration and proliferation. J Immunol 165: 15-19.

Brossard C, Feuillet V, Schmitt A, Randriamampita C, Romao M, Raposo G, Trautmann A. 2005. Multifocal structure of the T cell - dendritic cell synapse. Eur J Immunol 35: 1741-1753.

Brown MJ, Hallam JA, Colucci-Guyon E, Shaw S. 2001. Rigidity of circulating lymphocytes is primarily conferred by vimentin intermediate filaments. J Immunol 166: 6640-6646.

Brown MJ, Nijhara R, Hallam JA, Gignac M, Yamada KM, Erlandsen SL, Delon J, Kruhlak M, Shaw S. 2003. Chemokine stimulation of human peripheral blood $\mathrm{T}$ lymphocytes induces rapid dephosphorylation of ERM proteins, which facilitates loss of microvilli and polarization. Blood 102: 3890-3899.

Bunnell SC, Kapoor V, Trible RP, Zhang W, Samelson LE. 2001. Dynamic actin polymerization drives $\mathrm{T}$ cell receptor-induced spreading: a role for the signal transduction adaptor LAT. Immunity 14: 315-329.

Bunnell SC, Hong DI, Kardon JR, Yamazaki T, McGlade CJ, Barr VA, Samelson LE. 2002. T cell receptor ligation induces the formation of dynamically regulated signaling assemblies. J Cell Biol 158: 1263-1275.

Campi G, Varma R, Dustin ML. 2005. Actin and agonist MHC-peptide complex-dependent $\mathrm{T}$ cell receptor microclusters as scaffolds for signaling. J Exp Med 202: 1031-1036.

Cannon JL, Labno CM, Bosco G, Seth A, McGavin MH, Siminovitch KA, Rosen MK, Burkhardt JK. 2001. Wasp recruitment to the T cell: APC contact site occurs independently of Cdc42 activation. Immunity 15: 249-259.

Carpen O, Virtanen I, Lehto VP, Saksela E. 1983. Polarization of NK cell cytoskeleton upon conjugation with sensitive target cells. J Immunol 131: 2695-2698.

Cunningham BA, Hemperly JJ, Murray BA, Prediger EA, Brackenbury R, Edelman GM. 1987. Neural cell adhesion molecule: Structure, immunoglobulin-like domains, cell surface modulation, and alternative RNA splicing. Science 236: 799-806.

Davignon D, Martz E, Reynolds T, Kurzinger K, Springer TA. 1981. Lymphocyte function-associated antigen 1 
(LFA-1): A surface antigen distinct from Lyt-2,3 that participates in $\mathrm{T}$ lymphocyte-mediated killing. Proc Natl Acad Sci 78: 4535-4539.

Delon J, Kaibuchi K, Germain RN. 2001. Exclusion of CD43 from the immunological synapse is mediated by phosphorylation-regulated relocation of the cytoskeletal adaptor moesin. Immunity 15: 691-701.

DeMond AL, Mossman KD, Starr T, Dustin ML, Groves JT. 2008. T cell receptor microcluster transport through molecular mazes reveals mechanism of translocation. Biophys J 94: 3286-3292.

Dobereiner HG, Dubin-Thaler BJ, Hofman JM, Xenias HS, Sims TN, Giannone G, Dustin ML, Wiggins CH, Sheetz MP. 2006. Lateral membrane waves constitute a universal dynamic pattern of motile cells. Phys Rev Lett 97: 038102.

Douglass AD, Vale RD. 2005. Single-Molecule Microscopy Reveals Plasma Membrane Microdomains Created by Protein-Protein Networks that Exclude or Trap Signaling Molecules in T Cells. Cell 121: 937-950.

Dupre L, Aiuti A, Trifari S, Martino S, Saracco P, Bordignon C, Roncarolo MG. 2002. Wiskott-Aldrich syndrome protein regulates lipid raft dynamics during immunological synapse formation. Immunity 17: 157-166.

Dustin ML, Springer TA. 1988. Lymphocyte functionassociated antigen-1 (LFA-1) interaction with intercellular adhesion molecule-1 (ICAM-1) is one of at least three mechanisms for lymphocyte adhesion to cultured endothelial cells. J Cell Biol 107: 321-331.

Dustin ML, Springer TA. 1989. T cell receptor cross-linking transiently stimulates adhesiveness through LFA-1. Nature 341: 619-624.

Dustin ML, Colman DR. 2002. Neural and immunological synaptic relations. Science 298: 785-789.

Dustin ML, Cooper JA. 2000. The immunological synapse and the actin cytoskeleton: Molecular hardware for T cell signaling. Nat Immunol 1: 23-29.

Dustin ML, Rothlein R, Bhan AK, Dinarello CA, Springer TA. 1986. Induction by IL- 1 and interferon, tissue distri bution, biochemistry, and function of a natural adherence molecule (ICAM-1). J Immunol 137: 245-254.

Dustin ML, Sanders ME, Shaw S, Springer TA. 1987a. Purified lymphocyte function-associated antigen 3 binds to CD2 and mediates $\mathrm{T}$ lymphocyte adhesion. J Exp Med 165: 677-692.

Dustin ML, Selvaraj P, Mattaliano RJ, Springer TA. 1987b. Anchoring mechanisms for LFA-3 cell adhesion glycoprotein at membrane surface. Nature 329: 846-848.

Dustin ML, Olszowy MW, Holdorf AD, Li J, Bromley S, Desai N, Widder P, Rosenberger F, van der Merwe PA, Allen PM, et al. 1998. A novel adapter protein orchestrates receptor patterning and cytoskeletal polarity in T cell contacts. Cell 94: 667-677.

Egawa T, Albrecht B, Favier B, Sunshine MJ, Mirchandani K, O'Brien W, Thome M, Littman DR. 2003. Requirement for CARMA1 in antigen receptor-induced NF- $\mathrm{BB}$ activation and lymphocyte proliferation. Curr Biol 13: $1252-1258$.

Faure S, Salazar-Fontana LI, Semichon M, Tybulewicz VL, Bismuth G, Trautmann A, Germain RN, Delon J. 2004. ERM proteins regulate cytoskeleton relaxation promoting T cell-APC conjugation. Nat Immunol 5: 272-279.
Freiberg BA, Kupfer H, Maslanik W, Delli J, Kappler J, Zaller DM, Kupfer A. 2002. Staging and resetting T cell activation in SMACs. Nat Immunol 3: 911-917.

Gardner JM, Hynes RO. 1985. Interaction of fibronectin with its receptor on platelets. Cell 42: 439-448.

Geiger B, Rosen D, Berke G. 1982. Spatial relationships of microtubule-organizing centers and the contact area of cytotoxic T lymphocytes and target cells. J Cell Biol 95: 137-143.

Giannone G, Dubin-Thaler BJ, Dobereiner HG, Kieffer N, Bresnick AR, Sheetz MP. 2004. Periodic lamellipodial contractions correlate with rearward actin waves. Cell 116: $431-443$.

Giannone G, Dubin-Thaler BJ, Rossier O, Cai Y, Chaga O, Jiang G, Beaver W, Dobereiner HG, Freund Y, Borisy G, et al. 2007. Lamellipodial actin mechanically links Myosin activity with adhesion-site formation. Cell 128: 561-575.

Gomez TS, McCarney SD, Carrizosa E, Labno CM, Comiskey EO, Nolz JC, Zhu P, Freedman BD, Clark MR, Rawlings DJ, et al. 2006. HS1 Functions as an Essential Actin-Regulatory Adaptor Protein at the Immune Synapse. Immunity 24: 741-752.

Gomez TS, Kumar K, Medeiros RB, Shimizu Y, Leibson PJ, Billadeau DD. 2007. Formins regulate the actin-related protein 2/3 complex-independent polarization of the centrosome to the immunological synapse. Immunity 26: $177-190$.

Grakoui A, Bromley SK, Sumen C, Davis MM, Shaw AS, Allen PM, Dustin ML. 1999. The immunological synapse: A molecular machine controlling $\mathrm{T}$ cell activation. Science 285: 221-227.

Gunzer M, Schafer A, Borgmann S, Grabbe S, Zanker KS, Brocker EB, Kampgen E, Friedl P. 2000. Antigen presentation in extracellular matrix: Interactions of $\mathrm{T}$ cells with dendritic cells are dynamic, short lived, and sequential. Immunity 13: 323-332.

Gupton SL, Anderson KL, Kole TP, Fischer RS, Ponti A, Hitchcock-DeGregori SE, Danuser G, Fowler VM, Wirtz D, Hanein D, et al. 2005. Cell migration without a lamellipodium: Translation of actin dynamics into cell movement mediated by tropomyosin. J Cell Biol 168: 619-631.

Heissmeyer V, Macian F, Im SH, Varma R, Feske S, Venuprasad K, Gu H, Liu YC, Dustin ML, Rao A. 2004. Calcineurin imposes $\mathrm{T}$ cell unresponsiveness through targeted proteolysis of signaling proteins. Nat Immunol 5: 255-265.

Horwitz A, Duggan K, Greggs R, Decker C, Buck C. 1985. The cell substrate attachment (CSAT) antigen has properties of a receptor for laminin and fibronectin. J Cell Biol 101: 2134-2144.

Huse M, Lillemeier BF, Kuhns MS, Chen DS, Davis MM. 2006. T cells use two directionally distinct pathways for cytokine secretion. Nat Immunol 7: 247-255.

Ilani T, Khanna C, Zhou M, Veenstra TD, Bretscher A. 2007. Immune synapse formation requires ZAP-70 recruitment by ezrin and CD43 removal by moesin. J Cell Biol 179: 733-746.

Jacobelli J, Chmura SA, Buxton DB, Davis MM, Krummel MF. 2004. A single class II myosin modulates T cell 


\section{M.L. Dustin}

motility and stopping, but not synapse formation. Nat Immunol 5: 531-538.

Jay PY, Pham PA, Wong SA, Elson EL. 1995. A mechanical function of myosin II in cell motility. J Cell Sci 108: 387-393.

Jiang G, Giannone G, Critchley DR, Fukumoto E, Sheetz MP. 2003. Two-piconewton slip bond between fibronectin and the cytoskeleton depends on talin. Nature 424: 334-337.

Johnson KG, Bromley SK, Dustin ML, Thomas ML. 2000. A supramolecular basis for CD45 tyrosine phosphatase regulation in sustained T cell activation. Proc Natl Acad Sci 97: 10138-10143.

Kaizuka Y, Douglass AD, Varma R, Dustin ML, Vale RD. 2007. Mechanisms for segregating $T$ cell receptor and adhesion molecules during immunological synapse formation in Jurkat T cells. Proc Natl Acad Sci 104: 20296-20301.

Kato K, Koyanagi M, Okada H, Takanashi T, Wong YW, Williams AF, Okumura K, Yagita H. 1992. CD48 is a counter-receptor for mouse CD2 and is inolved in T cell activation. Journal of Experimental Medicine 176: 1241-1249.

Kim SV, Mehal WZ, Dong X, Heinrich V, Pypaert M, Mellman I, Dembo M, Mooseker MS, Wu D, Flavell RA. 2006. Modulation of cell adhesion and motility in the immune system by Myolf. Science 314: 136-139.

Kim JV, Kang SS, Dustin ML, McGavern DB. 2009. Myelomonocytic cell recruitment causes fatal CNS vascular injury during acute viral meningitis. Nature 457: 191-195.

Krawczyk C, Oliveira-dos-Santos A, Sasaki T, Griffiths E, Ohashi PS, Snapper S, Alt F, Penninger JM. 2002. Vavl controls integrin clustering and $\mathrm{MHC} /$ peptide-specific cell adhesion to antigen-presenting cells. Immunity $\mathbf{1 6}$ 331-343.

Krensky AM, Robbins E, Springer TA, Burakoff SJ. 1984. LFA-1, LFA-2, and LFA-3 antigens are involved in CTL-target conjugation. J Immunol 132: 2180-2182.

Kupfer A, Dennert G, Singer SJ. 1983. Polarization of the Golgi apparatus and the microtubule-organizing center within cloned natural killer cells bound to their targets. Proc Natl Acad Sci 80: 7224-7228.

Kupfer A, Swain SL, Janeway CA Jr, Singer SJ. 1986. The specific direct interaction of helper T cells and antigenpresenting B cells. Proc Natl Acad Sci 83: 6080-6083.

Kupfer A, Singer SJ. 1989. The specific interaction of helper T cells and antigen-presenting B cells. IV. Membrane and cytoskeletal reorganizations in the bound $\mathrm{T}$ cell as a function of antigen dose. J ExpMed 170: 1697-1713.

Labno CM, Lewis CM, You D, Leung DW, Takesono A, Kamberos N, Seth A, Finkelstein LD, Rosen MK, Schwartzberg PL, et al. 2003. Itk functions to control actin polymerization at the immune synapse through localized activation of Cdc42 and WASP. Curr Biol 13: 1619-1624.

Latour S, Roncagalli R, Chen R, Bakinowski M, Shi X, Schwartzberg PL, Davidson D, Veillette A. 2003. Binding of SAP SH2 domain to FynT SH3 domain reveals a novel mechanism of receptor signalling in immune regulation. Nat Cell Biol 5: 149-154.
Lawrence MB, Springer TA. 1991. Leukocytes roll on a selectin at physiologic flow rates: Distinction from and prerequisite for adhesion through integrins. Cell 65: 859-873.

Lee KY, D'Acquisto F, Hayden MS, Shim JH, Ghosh S. 2005. PDK1 nucleates $\mathrm{T}$ cell receptor-induced signaling complex for NF-кB activation. Science 308: 114-118.

Lindenmann J. 1984. Origin of the terms 'antibody' and 'antigen'. Scand J Immunol 19: 281-285.

Marlin SD, Springer TA. 1987. Purified intercellular adhesion molecule-1 (ICAM-1) is a ligand for lymphocyte function-associated antigen 1 (LFA-1). Cell 51: 813-819.

McIntyre BW, Allison JP. 1983. The mouse T cell receptor: Structural heterogeneity of molecules of normal T cells defined by xenoantiserum. Cell 34: 739-746.

Mempel TR, Henrickson SE, Von Andrian UH. 2004. T-cell priming by dendritic cells in lymph nodes occurs in three distinct phases. Nature 427: 154-159.

Miller MJ, Wei SH, Parker I, Cahalan MD. 2002 Two-photon imaging of lymphocyte motility and antigen response in intact lymph node. Science 296: 1869-1873.

Molon B, Gri G, Bettella M, Gomez-Mouton C, Lanzavecchia A, Martinez AC, Manes S, Viola A. 2005. $\mathrm{T}$ cell costimulation by chemokine receptors. Nat Immunol 6: 465-471.

Monks CR, Kupfer H, Tamir I, Barlow A, Kupfer A. 1997. Selective modulation of protein kinase C- $\theta$ during T-cell activation. Nature 385: 83-86.

Monks CR, Freiberg BA, Kupfer H, Sciaky N, Kupfer A. 1998. Three-dimensional segregation of supramolecular activation clusters in T cells. Nature 395: 82-86.

Morin NA, Oakes PW, Hyun YM, Lee D, Chin EY, King MR, Springer TA, Shimaoka M, Tang JX, Reichner JS, Kim M. 2008. Nonmuscle myosin heavy chain IIA mediates integrin LFA-1 de-adhesion during $\mathrm{T}$ lymphocyte migration. J Exp Med 205: 195-205.

Nagafuchi A, Shirayoshi Y, Okazaki K, Yasuda K, Takeichi M. 1987. Transformation of cell adhesion properties by exogenously introduced E-cadherin cDNA. Nature 329: 341-343.

Negulescu PA, Krasieva TB, Khan A, Kerschbaum HH, Cahalan MD. 1996. Polarity of T cell shape, motility, and sensitivity to antigen. Immunity 4: 421-430.

Nijhara R, van Hennik PB, Gignac ML, Kruhlak MJ, Hordijk PL, Delon J, Shaw S. 2004. Racl mediates collapse of microvilli on chemokine-activated $\mathrm{T}$ lymphocytes. J Immunol 173: 4985-4993.

Nolz JC, Gomez TS, Zhu P, Li S, Medeiros RB, Shimizu Y, Burkhardt JK, Freedman BD, Billadeau DD. 2006. The WAVE2 complex regulates actin cytoskeletal reorganization and CRAC-mediated calcium entry during $\mathrm{T}$ cell activation. Curr Biol 16: 24-34.

Nolz JC, Medeiros RB, Mitchell JS, Zhu P, Freedman BD, Shimizu Y, Billadeau DD. 2007. WAVE2 regulates highaffinity integrin binding by recruiting vinculin and talin to the immunological synapse. Mol Cell Biol 27: 5986-6000.

Nolz JC, Nacusi LP, Segovis CM, Medeiros RB, Mitchell JS, Shimizu Y, Billadeau DD. 2008. The WAVE2 complex regulates $\mathrm{T}$ cell receptor signaling to integrins via 
Abl- and CrkL-C3G-mediated activation of Rap1. J Cell Biol 182: 1231-1244.

Norcross MA. 1984. A synaptic basis for T-lymphocyte activation. Ann Immunol 135D: 113-134.

Oddos S, Dunsby C, Purbhoo MA, Chauveau A, Owen DM, Neil MA, Davis DM, French PM. 2008. High-speed highresolution imaging of intercellular immune synapses using optical tweezers. Biophys J 95: L66-68.

Okada T, Miller MJ, Parker I, Krummel MF, Neighbors M, Hartley SB, O'Garra A, Cahalan MD, Cyster JG. 2005. Antigen-engaged B cells undergo chemotaxis toward the $\mathrm{T}$ zone and form motile conjugates with helper T cells. PLoS Biol 3: e150.

Paul WE, Seder RA. 1994. Lymphocyte responses and cytokines. Cell 76: 241-251.

Peyrieras N, Hyafil F, Louvard D, Ploegh HL, Jacob F. 1983. Uvomorulin: A nonintegral membrane protein of early mouse embryo. Proc Natl Acad Sci 80: 6274-6277.

Pierce RA, Field ED, Mutis T, Golovina TN, Von Kap-Herr C, Wilke M, Pool J, Shabanowitz J, Pettenati MJ, Eisenlohr LC, et al. 2001. The HA-2 minor histocompatibility antigen is derived from a diallelic gene encoding a novel human class I myosin protein. J Immunol 167: 3223-3230.

Pytela R, Pierschbacher MD, Ruoslahti E. 1985. A 125/ $115-\mathrm{kDa}$ cell surface receptor specific for vitronectin interacts with the arginine-glycine-aspartic acid adhesion sequence derived from fibronectin. Proc Natl Acad Sci 82: 5766-5770.

Qi H, Cannons JL, Klauschen F, Schwartzberg PL, Germain RN. 2008. SAP-controlled T-B cell interactions underlie germinal centre formation. Nature 455: 764-769.

Rothlein R, Springer TA. 1986. The requirement for lymphocyte function-associated antigen 1 in homotypic leukocyte adhesion stimulated by phorbol ester. $J$ Exp Med 163: 1132-1149.

Rothlein R, Dustin ML, Marlin SD, Springer TA. 1986. A human intercellular adhesion molecule (ICAM-1) distinct from LFA-1. J Immunol 137: 1270-1274.

Rutishauser U, Hoffman S, Edelman GM. 1982. Binding properties of a cell adhesion molecule from neural tissue. Proc Natl Acad Sci 79: 685-689.

Sanchez-Madrid F, del Pozo MA. 1999. Leukocyte polarization in cell migration and immune interactions. Embo J 18: 501-511.

Sanchez-Madrid F, Krensky AM, Ware CF, Robbins E, Strominger JL, Burakoff SJ, Springer TA. 1982. Three distinct antigens associated with human T-lymphocytemediated cytolysis: LFA-1, LFA-2, and LFA-3. Proc Natl Acad Sci 79: 7489-7493.

Sasahara Y, Rachid R, Byrne MJ, de la Fuente MA, Abraham RT, Ramesh N, Geha RS. 2002. Mechanism of recruitment of WASP to the immunological synapse and of its activation following TCR ligation. Mol Cell 10: 1269-1281.

Savage ND, Kimzey SL, Bromley SK, Johnson KG, Dustin ML, Green JM. 2002. Polar redistribution of the sialoglycoprotein CD43: Implications for $\mathrm{T}$ cell function. $J$ Immunol 168: 3740-3746.

Schmits R, Kundig TM, Baker DM, Shumaker G, Simard JJ, Duncan G, Wakeham A, Shahinian A, van der Heiden A,
Bachmann MF, et al. 1996. LFA-1-deficient mice show normal CTL responses to virus but fail to reject immunogenic tumor. J Exp Med 183: 1415-1426.

Schwickert TA, Lindquist RL, Shakhar G, Livshits G, Skokos D, Kosco-Vilbois MH, Dustin ML, Nussenzweig MC. 2007. In vivo imaging of germinal centres reveals a dynamic open structure. Nature 446: 83-87.

Selvaraj P, Plunkett ML, Dustin M, Sanders ME, Shaw S, Springer TA. 1987. The T lymphocyte glycoprotein CD2 (LFA-2/T11/E-Rosette receptor) binds the cell surface ligand LFA-3. Nature 326: 400-403.

Shaffer MH, Dupree RS, Zhu P, Saotome I, Schmidt RF, McClatchey AI, Freedman BD, Burkhardt JK. 2009. Ezrin and moesin function together to promote $\mathrm{T}$ cell activation. J Immunol 182: 1021-1032.

Shamri R, Grabovsky V, Gauguet JM, Feigelson S, Manevich E, Kolanus W, Robinson MK, Staunton DE, von Andrian UH, Alon R. 2005. Lymphocyte arrest requires instantaneous induction of an extended LFA- 1 conformation mediated by endothelium-bound chemokines. Nat Immunol 6: 497-506.

Shaw S, Luce GE, Quinones R, Gress RE, Springer TA, Sanders ME. 1986. Two antigen-independent adhesion pathways used by human cytotoxic T-cell clones. Nature 323: 262-264.

Shimaoka M, Xiao T, Liu JH, Yang Y, Dong Y, Jun CD, McCormack A, Zhang R, Joachimiak A, Takagi J, et al. 2003. Structures of the alpha L I domain and its complex with ICAM-1 reveal a shape-shifting pathway for integrin regulation. Cell 112: 99-111.

Sims TN, Soos TJ, Xenias HS, Dubin-Thaler B, Hofman JM, Waite JC, Cameron TO, Thomas VK, Varma R, Wiggins $\mathrm{CH}$, et al. 2007. Opposing Effects of PKC- $\theta$ and WASp on Symmetry Breaking and Relocation of the Immunological Synapse. Cell 129: 773-785.

Skokos D, Shakhar G, Varma R, Waite JC, Cameron TO, Lindquist RL, Schwickert T, Nussenzweig MC, Dustin ML. 2007. Peptide-MHC potency governs dynamic interactions between $\mathrm{T}$ cells and dendritic cells in lymph nodes. Nat Immunol 8: 835-844.

Smith A, Carrasco YR, Stanley P, Kieffer N, Batista FD, Hogg N. 2005. A talin-dependent LFA-1 focal zone is formed by rapidly migrating $\mathrm{T}$ lymphocytes. J Cell Biol 170: $141-151$.

Snapper SB, Rosen FS, Mizoguchi E, Cohen P, Khan W, Liu CH, Hagemann TL, Kwan SP, Ferrini R, Davidson L, et al. 1998. Wiskott-Aldrich syndrome protein-deficient mice reveal a role for WASP in T but not B cell activation. Immunity 9: 81-91.

Somersalo K, Anikeeva N, Sims TN, Thomas VK, Strong RK, Spies T, Lebedeva T, Sykulev Y, Dustin ML. 2004. Cytotoxic T lymphocytes form an antigen-independent ring junction. J Clin Invest 113: 49-57.

Springer TA. 1990. Adhesion receptors of the immune system. Nature 346: 425-434.

Springer TA. 1995. Traffic signals on endothelium for lymphocyte recirculation and leukocyte emigration. Annu Rev Physiol 57: 827-872.

Staunton DE, Dustin ML, Springer TA. 1989. Functional cloning of ICAM-2, a cell adhesion ligand for LFA-1 homologous to ICAM-1. Nature 339: 61-64. 


\section{M.L. Dustin}

Stinchcombe JC, Majorovits E, Bossi G, Fuller S, Griffiths GM. 2006. Centrosome polarization delivers secretory granules to the immunological synapse. Nature 443: $462-465$.

Sumen C, Dustin ML, Davis MM. 2004. T cell receptor antagonism interferes with MHC clustering and integrin patterning during immunological synapse formation. J Cell Biol 166: 579-590.

Sun Z, Arendt CW, Ellmeier W, Schaeffer EM, Sunshine MJ, Gandhi L, Annes J, Petrzilka D, Kupfer A, Schwartzberg PL, et al. 2000. PKC- $\theta$ is required for TCR-induced NF- $\kappa \mathrm{B}$ activation in mature but not immature T lymphocytes. Nature 404: 402-407.

Tadokoro S, Shattil SJ, Eto K, Tai V, Liddington RC, De Pereda JM, Ginsberg MH, Calderwood DA. 2003. Talin binding to integrin $\beta$ tails: A final common step in integrin activation. Science 302: 103-106.

Trombetta ES, Mellman I. 2005. Cell biology of antigen processing in vitro and in vivo. Annu Rev Immunol 23: 975-1028.

Tseng SY, Waite JC, Liu M, Vardhana S, Dustin ML. 2008. $\mathrm{T}$ cell-dendritic cell immunological synapses contain TCR-dependent CD28-CD80 clusters that recruit protein kinase C- $\theta$. J Immunol 181: 4852-4863.

Tskvitaria-Fuller I, Rozelle AL, Yin HL, Wulfing C. 2003. Regulation of sustained actin dynamics by the TCR and costimulation as a mechanism of receptor localization. J Immunol 171: 2287-2295.

Underhill DM, Bassetti M, Rudensky A, Aderem A. 1999. Dynamic interactions of macrophages with $T$ cells during antigen presentation. J Exp Med 190: 1909-1914.

Varma R, Campi G, Yokosuka T, Saito T, Dustin ML. 2006 $\mathrm{T}$ cell receptor-proximal signals are sustained in peripheral microclusters and terminated in the central supramolecular activation cluster. Immunity 25: $117-127$.
Wei X, Tromberg BJ, Cahalan MD. 1999. Mapping the sensitivity of $\mathrm{T}$ cells with an optical trap: Polarity and minimal number of receptors for $\mathrm{Ca}(2+)$ signaling. Proc Natl Acad Sci 96: 8471-8476.

White J, Haskins KM, Marrack P, Kappler J. 1983. Use of I region-restricted, antigen-specific $\mathrm{T}$ cell hybridomas to produce idiotypically specific anti-receptor antibodies. J Immunol 130: 1033-1037.

Wong YW, Williams AF, Kingsmore SF, Seldin MF. 1990. Structure, expression, and genetic linkage of the mouse BCM1 (OX45 or Blast-1) antigen. Evidence for genetic duplication giving rise to the $\mathrm{BCM} 1$ region on mouse chromosome 1 and the CD2/LFA3 region on mouse chromosome 3. J Exp Med 171: 2115-2130.

Woolf E, Grigorova I, Sagiv A, Grabovsky V, Feigelson SW, Shulman Z, Hartmann T, Sixt M, Cyster JG, Alon R. 2007. Lymph node chemokines promote sustained $T$ lymphocyte motility without triggering stable integrin adhesiveness in the absence of shear forces. Nat Immunol 8: 1076-1085.

Wright SD, Meyer BC. 1985. Fibronectin receptor of human macrophages recognizes the sequence Arg-Gly-Asp-Ser. J Exp Med 162: 762-767.

Yokosuka T, Sakata-Sogawa K, Kobayashi W, Hiroshima M, Hashimoto-Tane A, Tokunaga M, Dustin ML, Saito T. 2005. Newly generated $\mathrm{T}$ cell receptor microclusters initiate and sustain $\mathrm{T}$ cell activation by recruitment of Zap70 and SLP-76. Nat Immunol 6: 1253-1262.

Yokosuka T, Kobayashi W, Sakata-Sogawa K, Takamatsu M, Hashimoto-Tane A, Dustin ML, Tokunaga M, Saito T. 2008. Spatiotemporal regulation of T cell costimulation by TCR-CD28 microclusters and protein kinase C- $\theta$ translocation. Immunity 29: 589-601.

Zhu J, Luo BH, Xiao T, Zhang C, Nishida N, Springer TA. 2008. Structure of a complete integrin ectodomain in a physiologic resting state and activation and deactivation by applied forces. Mol Cell 32: 849-861. 


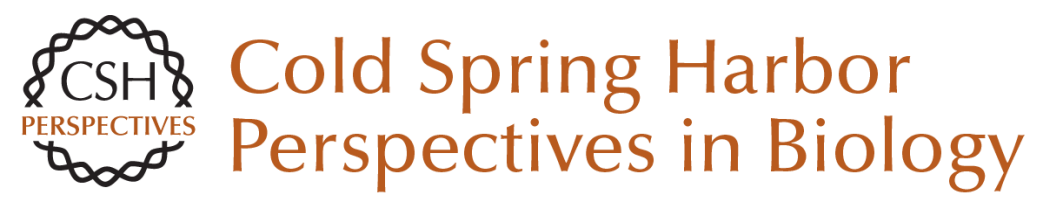

\section{Modular Design of Immunological Synapses and Kinapses}

Michael L. Dustin

Cold Spring Harb Perspect Biol 2009; doi: 10.1101/cshperspect.a002873

Subject Collection Cell-Cell Junctions

Vascular Endothelial (VE)-Cadherin, Endothelial

Adherens Junctions, and Vascular Disease

Maria Grazia Lampugnani, Elisabetta Dejana and

Costanza Giampietro

Adherens Junctions and Desmosomes

Coordinate Mechanics and Signaling to

Orchestrate Tissue Morphogenesis and Function:

An Evolutionary Perspective Matthias Rübsam, Joshua A. Broussard, Sara A. Wickström, et al.

Cell-Cell Contact and Receptor Tyrosine Kinase

Signaling

Christine Chiasson-MacKenzie and Andrea I. McClatchey

Hold Me, but Not Too Tight--Endothelial Cell-Cell Junctions in Angiogenesis Anna Szymborska and Holger Gerhardt

Connexins and Disease Mario Delmar, Dale W. Laird, Christian C. Naus, et al.

Cell Junctions in Hippo Signaling Ruchan Karaman and Georg Halder

Loss of E-Cadherin-Dependent Cell-Cell Adhesion and the Development and Progression of Cancer Heather C. Bruner and Patrick W.B. Derksen
Signaling by Small GTPases at Cell-Cell Junctions: Protein Interactions Building Control and Networks

Vania Braga

Making Connections: Guidance Cues and Receptors at Nonneural Cell-Cell Junctions Ian V. Beamish, Lindsay Hinck and Timothy E. Kennedy

The Cadherin Superfamily in Neural Circuit Assembly James $D$. Jontes

Mechanosensing and Mechanotransduction at Cell-Cell Junctions Alpha S. Yap, Kinga Duszyc and Virgile Viasnoff

Beyond Cell-Cell Adhesion: Sensational Cadherins for Hearing and Balance Avinash Jaiganesh, Yoshie Narui, Raul Araya-Secchi, et al.

Cell-Cell Junctions Organize Structural and Signaling Networks Miguel A. Garcia, W. James Nelson and Natalie Chavez

Cell Biology of Tight Junction Barrier Regulation and Mucosal Disease Aaron Buckley and Jerrold R. Turner

For additional articles in this collection, see http://cshperspectives.cshlp.org/cgi/collection/

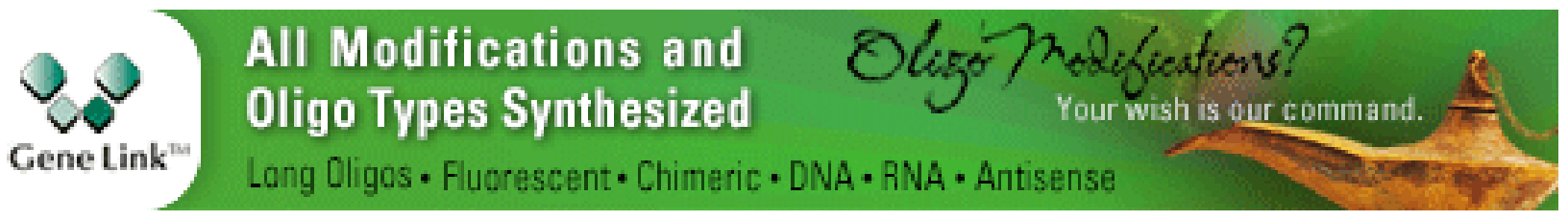


Desmosomes and Intermediate Filaments: Their Consequences for Tissue Mechanics Mechthild Hatzfeld, René Keil and Thomas M. Magin
Integration of Cadherin Adhesion and

Cytoskeleton at Adherens Junctions

René Marc Mège and Noboru Ishiyama

For additional articles in this collection, see http://cshperspectives.cshlp.org/cgi/collection/

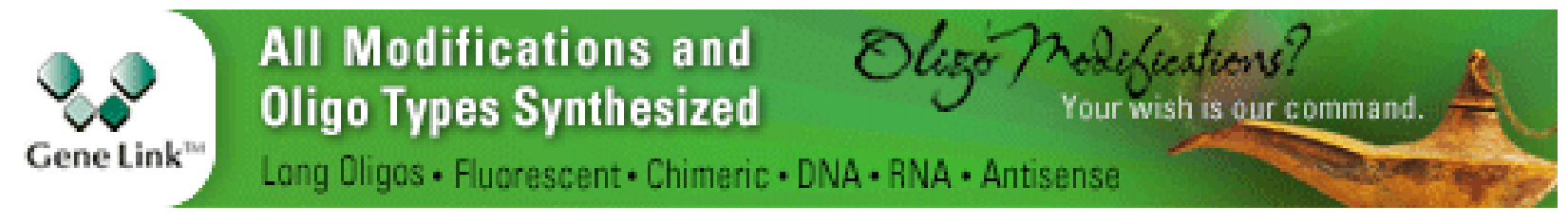

Copyright @ 2009 Cold Spring Harbor Laboratory Press; all rights reserved 